\title{
STRUKTUR FORMAL FASADE BANGUNAN UTAMA BERSEJARAH (Kawasan Kota Lama Semarang)
}

\author{
Deni Wahyu Setiawan ${ }^{1,2 *}$ ) Agung Budi Sardjono ${ }^{2}$, R.Siti Rukayah ${ }^{2}$, Bangun I.R. Harsritanto ${ }^{2}$ \\ *) Corresponding author email : deniws05@gmail.com \\ 1) CV. Realine Desain Lab, Semarang - Indonesia \\ 2)Departemen Arsitektur, Fakultas Teknik, Universitas Diponegoro, Semarang - Indonesia
}

\author{
Article info \\ MODUL vol 20 no 1 , issues period 2020 \\ Doi $\quad: 10.14710 / \mathrm{mdl} .20 .1 .2020 .75-83$ \\ Received : 11 April 2020 \\ Revised : 5 mei 2020 \\ Accepted : 12 mei 2020
}

\begin{abstract}
Struktur suatu kawasan berkembang dan dikembangkan melalui suatu aturan yang terkadang berubah-ubah tetapi dapat menghasilkan keselarasan. Kota Lama Semarang terbentuk sejak zaman VOC berdiri di Nusantara. Proses perkembangan bangunan dan infrastrukturnya tidak terjadi hanya pada satu kurun waktu. Beragam fungsi bangunan yang mengisi Kawasan benteng kota lama Semarang membuat kehidupan di dalamnya dapat bertahan. Pada era kiwari, fungsi bangunan dan tambah-kurang bangunan terjadi di Kawasan ini. Perubahan tersebut kurang dapat dirasakan jika kita melewati Kawasan bersejarah ini. Penelitian ini bertujuan untuk menganalisa struktur formal fasade bangunan utama di dalam Kawasan Benteng Kota Lama Semarang. Hasil observasi lapangan yang dibahas menggunakan literatur tentang struktur formal, fasade, dan kajian historiografi untuk menghasilkan dugaan struktur formal pada fasade bangunan utama di Kawasan ini.
\end{abstract}

Keywords: struktur formal; fasade; bangunan

bersejarah, kota lama semarang

\section{Pendahuluan}

Kaum penjelajah dunia era klasik dari Eropa yang datang ke Indonesia menurut sejarah, yaitu : Portugis, Spanyol, Inggris dan Belanda. Tujuan awal kunjungan mereka adalah gold, gospel, glory (kekayaan, keyakinan dan penaklukan). Mereka membangun area Eropa untuk menetap di beberapa kota di Indonesia, terutama di daerah yang dekat dengan pelabuhan laut (teluk/semenanjung) atau pelabuhan darat (sungai besar) Pada saat ini mayoritas mereka membuat dinding rumah dari kayu dan papan dengan penutup atap ijuk karena tidak ada jerami/gandum di Indonesia. Bangsa Eropa akhirnya berusaha menguasai berbagai sendi perekonomian di Indonesia akibat rempah-rempah dan sering terjadi konflik diantara mereka sendiri karena pembagian wilayah dan kekuasaan yang tidak terstruktur. Di lain pihak, bangsa Indonesia sendiri tidak menyukai sistem perdagangan yang Eropa jalankan, sehingga konflik tak terhindarkan antara bangsa Indonesia dan bangsa Eropa. Akibat konflik-konflik itu, maka bangsa Eropa di Indonesia merasa tidak nyaman dan terancam keamanannya. Pada fase selanjutnya mereka mulai membangun benteng kokoh untuk menandai wilayah dan perlindungan. Pada umumnya dinding luar benteng tersebut dibentuk dari tanah liat dengan ketinggian 2,5 m dan tebal $1 \mathrm{~m}$. Benteng-benteng seperti itu dapat kita jumpai pada setiap setiap kota-kota besar dan kota niaga di Indonesia. Banyak dinding benteng dan kota benteng dibangun sebagai pusat kekuatan militer dan pusat fasilitas pendukung strategis bagi pemerintahan Hindia Belanda, seperti di Ambon, Ternate, Makasar, Banten, Batavia dan Semarang. Di Ambon dibangun benteng pada tahun 1580 dengan nama Benteng Victoria, di Makasar bernama Benteng Rotterdam, di Jakarta pada tahun 1611 dengan nama Benteng Batavia dan di Semarang dengan nama Benteng Vifjhoek (gambar 1).

Pemerintahan kolonial Belanda di Semarang pada saat awal membangun benteng sebagai pusat militer. Benteng ini berbentuk segi lima dan pertama kali dibangun di sisi barat kota lama Semarang saat ini. Benteng ini hanya memiliki satu gerbang di sisi selatannya dan lima Menara pengawas. Masing-masing menara diberi nama: Zeeland, Amsterdam, Utrecht, Raamsdonk dan Bunschoten (lihat gambar 1). Perwakilan kerajaan Belanda pernah melakukan resettlement bangsa Tionghoa terkait Wijkend stelsel pada tahun 1731 di dekat pemukiman Belanda, untuk 
memudahkan pengawasan terhadap segala aktifitas orang Cina selain untuk benteng pertahanan militer. Sejak VOC hingga pemerintahan kerajaan Belanda, bangunan di dalam benteng ini silih berganti dibangun sesuai dengan kebutuhan saat itu (Purwanto, 2005).

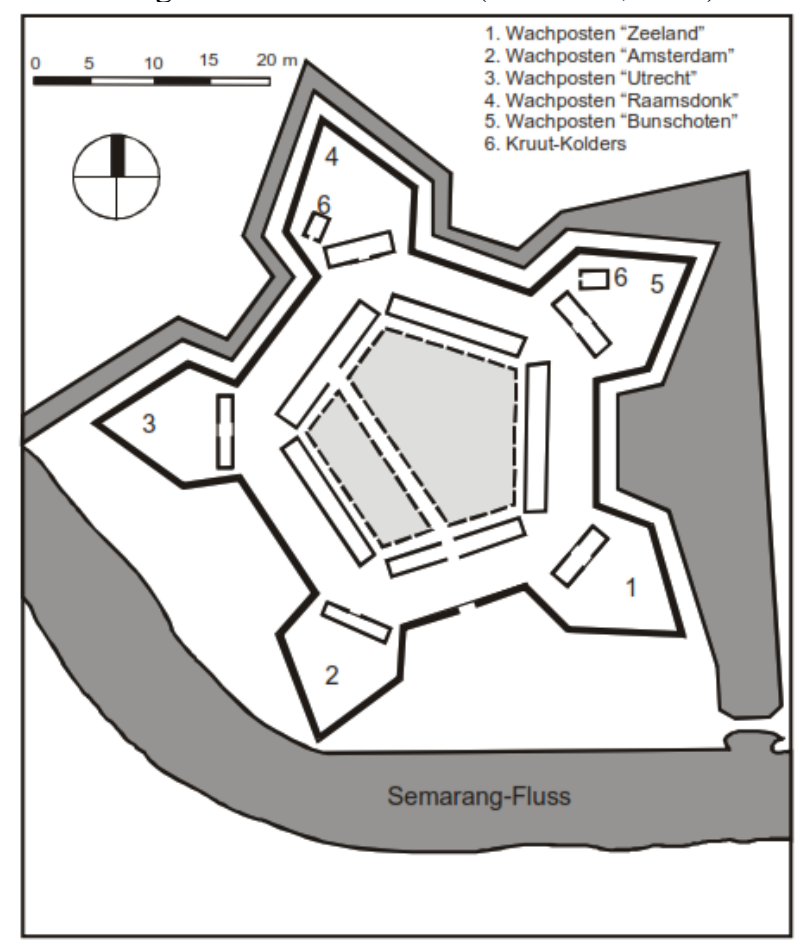

gambar 1. Benteng Vihfhoek (Purwanto, 2005)

Semarang sebagai kota pelabuhan, pada era kolonialisme Belanda memiliki peran strategis untuk kegiatan persediaan pangan komersial dan pertahanan keamanan yang terwujud dalam bangunan kantor. Pemerintahan kolonial belanda memerlukan bangunan kantor untuk menjalankan aktifitasnya. Bangunan kantor peninggalan kolonial belanda kini masih ada yang dilestarikan dan ada pula yang sudah terlanjur didemolisi. Untuk menunjang militer dan komersial, Semarang juga dilengkapi dengan sarana ibadah, pusat kebudayaan, instalasi energi dan perhubungan darat-laut. Hal tersebut dapat kita lihat hingga sekarang di sekitar kawasan kota lama ini (lihat gambar 2).

Kawasan kota lama Semarang menjadi pusat perdagangan pada abad ke 19-20 di Jawa selain Batavia di Barat dan Surabaya di Timur. Kawasan ini telah menjadi saksi bisu sejarah Indonesia pada masa kolonial belanda lebih dari 200 tahunan, dan lokasinya berdampingan dengan kawasan ekonomi zaman sekarang. Di tempat ini terdapat sekitar 50 bangunan kuno yang masih berdiri dan mempunyai sejarah kolonialisme di kota Semarang (lihat gambar 3). Kawasan Kota Lama Semarang memiliki keunikan dan keindahan suasana bangunan dengan arsitektur Eropa yang jarang terdapat dikota lain. Nilai kelangkaan dan nilai sejarah yang di miliki kawasan Kota Lama (Rahmi dan Roychansyah, 2017). Kota Lama Semarang mewakili citra visual kawasan yang menyajikan kemegahan arsitektur Eropa di masa lalu. Lokasi Kota Lama Semarang yang terpisah dengan lansekap memiliki kemiripan dengan banyak kota di Eropa, terlabih lagi keberadaan kanal yang mengelilinginya menjadikan Kota Lama seperti miniature Belanda di Semarang. Oleh sebab itu, Kota Lama dijuluki sebagai "Little Netherland" di Semarang (Setioko dan Harsritanto, 2017).

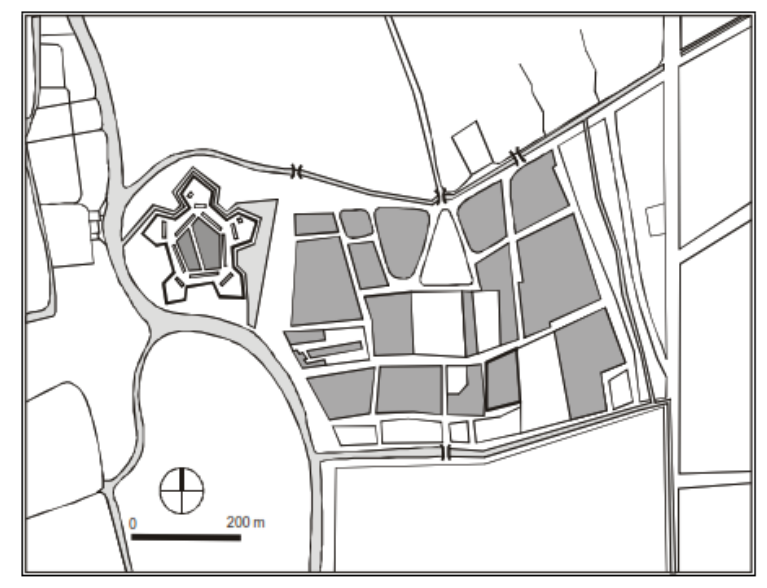

gambar 2. Kota Lama Semarang era 1720 (Purwanto, 2005)

Arsitektur kolonial Belanda di Kota Lama Semarang secara detail sebenarnya adalah arsitektur dengan beraneka ragam fasad bangunan yang mampu memberikan ciri khas arsitektur atau tipologi bangunan tertentu. Karakteristik bangunan bangunan Belanda yang terlihat juga sedikit banyak mengalami perubahan dari aslinya yang beradaptasi dengan kondisi lingkungan di kota Semarang yang beriklim tropis (Indraswara, 2011).

Keunikan tersebut membuat usaha pariwisata dan pembangunan baru pada kawasan dalam benteng Kota Lama pada satu dasa warsa ini. untuk mengatasi berbagai persoalan menyangkut eksistensi Kota Lama Semarang yang saat ini juga sudah dimasukan dalam tentative list world heritage oleh UNESCO, maka semua komponen pemerintah dan masyarakat harus bekerja keras untuk melakukan perawatan dan pengelolaan kota tua ini tidak hanya sebatas fisik. Perawatan dan pengelolaan itu harus juga harus memahami prinsipprinsip konservasi (Sari dkk, 2017). 


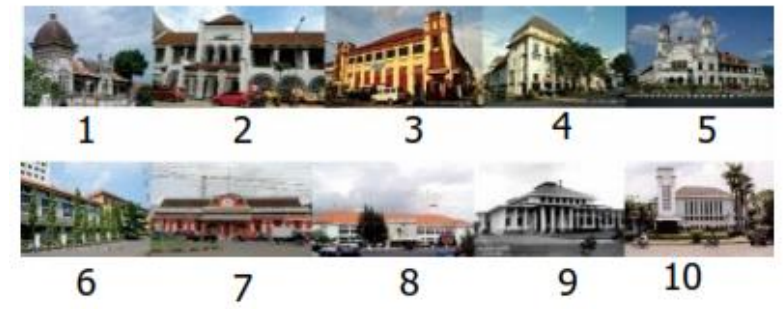

Gambar 3. Sampel Tipologi bangunan kota lama

Semarang (Rahmi dan Roychansyah, 2017)

Pendirian bangunan-bangunan kolonial maupun yang baru ternyata tidak membuat tampilan fasade bangunan yang berada dalam Kawasan Benteng Kota Lama berbeda-beda dan rumit (lihat gambar 3). Hal tersebut menurut pemahaman konservasi di Indonesia yang secara hukum dilandaskan pada UU RI no 5 tahun 1992 tentang cagar budaya, kesadaran masyarakat menjaga benda bersejarah dan kehandalan juga keunikan kawasan dan bangunan itu sendiri yang menjaga otentisitasnya.

Nilai otentisitas yang menyatukan suatu kawasan yang beragam kurun waktu pendiriaanya itu dapat dikatakan memiliki struktur formal yang entah disepakati atau terjadi natural terbentuk. Penelitian ini bertujuan untuk menganalisa struktur formal fasade bangunan utama di dalam Kawasan Benteng Kota Lama Semarang. Pendekatan kualitatif dari temuan-temuan lapangan yang dibahas dengan teori yang sesuai dilakukan secara terstruktur untuk merumuskan struktur formal kawasan bersejarah kota lama Semarang.

\section{Metode Meneliti dan Membahas}

Penelitian ini merupakan bagian dari tesis dengan menggunakan paradigma kualitatif. Metode kualitatif ialah prosedur yang menghasilkan data berupa data tertulis atau lisan yang bukan numerikal.

Tahap-tahap operasional dalam melakukan penelitian ini adalah :

1. Tahap Persiapan

Tahap persiapan meliputi tinjauan Pustaka terkait struktur formal, fasade, bangunan bersejarah dan pengkerucutan objek bangunan utama di Kawasan kota lama yang semuanya terletak di jalan utama Letjend. Suprapto, menjadi: Gedung Marba, Gereja Blenduk, dan Gedung Jiwa Sraya

2. Tahap Pengumpulan Data

Melakukan observasi lapangam, interview serta studi pustaka yang sesuai dengan tema struktur formal dan fasade bangunan.

3. Tahap Analisis

Mulai menganalisis hasil yang ditemukan pada lapangan, disesuaikan dengan teori-teori struktur formal, fasade, konsevasi cagar budaya dan estetika.

4. Tahap Penarikan Kesimpulan

Melakukan penarikan simpulan berdasarkan analisis.

\section{Tahap Persiapan dengan Struktur Formal}

Goran Schildt pada Gamble (2014) berpendapat bahwa ruang (bangunan) tidak terpengaruh pada berbagai skema stereometris dan selalu berkepentingan dengan macam kepentingan tentang eksistensinya. Terkadang suatu konsep tidak mewakili karakteristik dari bangunan tersebut karena ada perkembangan yang terjadi pada saat dibangun atau telah digunakan. Hal tersebut dikuatkan oleh Aalto pada kuliahnya tentang bentuk sebagai simbol kreatifitas artistik dalam Gamble (2014) I would like to discuss the concept of form.

"Form itself is like the earth's crust, the inner and the outer crust; more important still, form is the symbol of the organic content of human activity. Where the form is good, there the activity will usually also be good. Form must be a logical, coordinating force in that which we call a building, a town, or a group of buildings"

Aalto menyebutkan bahwa bentuk (form) seperti serpihan bumi dengan bagian dalam dan luar, tetapi bentuk sendiri adalah simbol dari konten kegiatan manusia yang organis dan natural. Pada bentuk yang bagus biasanya akan terdapat kegiatan yang juga bagus. Bentuk harus logis dengan kekuatan koordinatif yang kita sebut bangunan, lingkungan atau kawasan.

Dari penjelasan Alvar Aalto dalam Gamble di atas dapat kita sarikan bahwa struktur formal merupakan hal yang cocok dijadikan bahan pembahasan pada kawasan kota lama ini. Karena pembentukan kota lama ini telah menempuh berbagai konsep perancangan, tetapi sampai sekarang masih berkembang secara organis dan natural (lihat gambar 4).

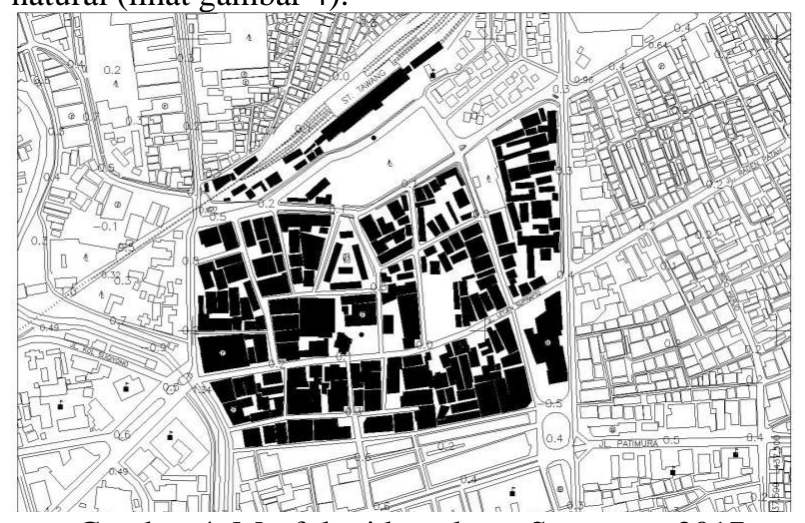

Gambar 4. Morfologi kota lama Semarang 2017

(Setioko dan Harsritanto, 2017) 
Jika kita bandingkan gambar 2 dan gambar 4 yang mewakili rentang waktu 300 tahun atau tiga abad, perubahan struktur bangunan terjadi terutama pada hilangnya benteng, tetapi struktur kawasan hampir dikatakan tidak ada perubahan mendasar. Hal tersebut menegaskan adanya kekuatan struktur formal yang secara berabad-abad terbentuk dan menguat terutama dengan hancurnya benteng bintang segilima tersebut.

\section{Prinsip Struktur Formal terkait estetika fasade}

Menurut Architeacher dalam Pazooki (2011) posisi estetika dalam fasade bangunan dapat membentuk suatu struktur formal dengan ketentuan sebagai berikut :
1. Kontras
2. Proporsi
3. Skala
4. Keseimbangan
5. Ritme
6. Kesatuan
7. Karakter

Posisi kontras dijelaskan oleh Salyan dan Thapa (2000) sebagai upaya memberikan kesan tersendiri terhadap suatu bangunan. Meskipun tampilannya mirip, suatu bangunan yang memiliki kontras yang baik terhadap lingkungannya tidak akan mudah terlewati Ketika dilalui dan mendukung aspek karakternya. Dapat kita lihat gambar 5 yang memperlihatkan kontras bangunan-bangunan di sekitaran taman Srigunting, Kota Lama.

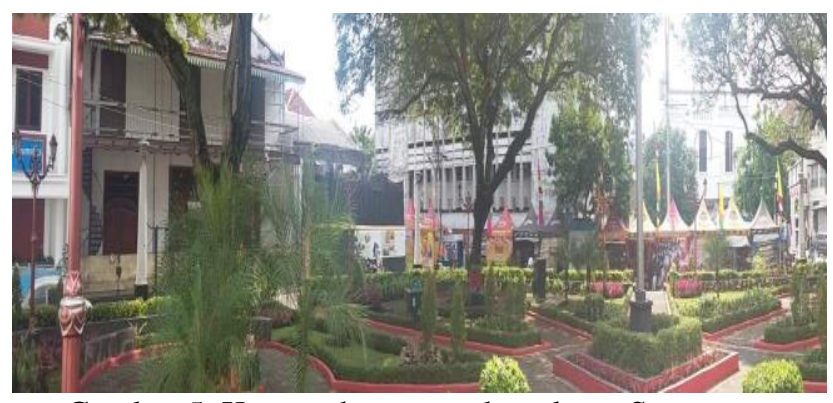

Gambar 5. Kontras bangunan kota lama Semarang (Setioko dan Harsritanto, 2017)

Proporsi terkait dengan perbandingan suatu elemen terhadap elemen lain. Hal paling penting dari proporsi yang estetis dari bangunan adalah fasadenya (Salyan dan Thapa, 2000). Mayoritas Gedung-gedung di area kota lama merupakan bangunan dengan dua lantai dan menggunakan penonjolan elemen penghias struktur yang sebenarnya struktur bangunan sendiri tidak terlihat karena menggunakan dinding satu batu (lihat gambar 6).

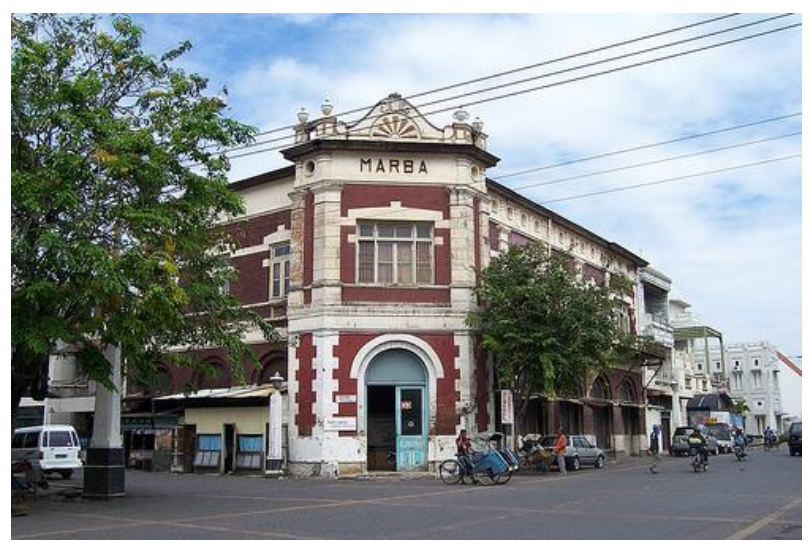

Gambar 6. Proporsi gedung Marba terhadap sekitarnya (Setioko dan Harsritanto, 2017)

Skala menurut Ching (2007) memiliki kaitan erat dengan proporsi. Skala membutuhkan suatu referensi untuk dijadikan acuan penskalaan. Dalam bangunan di kota lama, skala manusia dan lingkungan cukup terlihat dari fasade yang tercipta dari bangunan bertingkat duanya maupun bangunan satu lantai (lihat gambar 5).

Keseimbangan menurut Salyan dan Thapa (2000) erat kaitannya dengan pemberian nilai dan harmonisasinya. Hal tersebut dijelaskan lebih detail oleh Jefferis dan Madsen (1986) bahwa keseimbangan itu tidak harus simetri, kiri dan kanan sama besar bentuk maupun coraknya. Keseimbangan dapat tercipta dari pola asimetri selama nilai yang tercipta dan dipahami masih berimbang setara. Mayoritas bangunan di kota lama berazas simetris pada kedua sisi kanan-kirinya.

Bangunan bisa dikatakan tidak perlu statis dan terdiam dalam pondasi strukturnya. Pergerakan dapat terjadi dengan perjalanan tema pada fasadenya. Saat mengamati bangunan kita dapat berhenti sejenak berkali kali untuk memperhatikan suatu detil sebelum kemudian melanjutkan ke bagian yang menarik lain (Salyan dan Tappa,2020) (Pazooki, 2011). Pergerakan tersebut dikatakan ritme yang membuat pengamatnya tidak jenuh untuk mengikutnya. Bangunan di area penelitian memiliki berbagai pengulangan pada fasadenya.

Kesatuan itu terdiri dari unsur perbedaan dan ritme (Jefris dan Madsen, 1986). Sebuah kesatuan bentuk itu dapat terbentuk melalui konfigurasi titik, garis, bidang dan elemen lain (Ching, 2007). Sehingga dapat dirumuskan bahwa kesatuan itu ada jika terdapat fungsi/tujuan yang sama dari elemen-elemen yang berbeda yang membentuk suatu ritme tertentu.

Karakter dapat timbul dari fungsi, kedekatan asosiatif, identitas suatu elemen bangunan dengan komposisi penataan kreativitas tertentu Salyan dan Thapa, 2000).

Menurut Rob Krier (1988), fasade merupakan elemen arsitektur yang mengekspresikan fungsi dan maksud sebuah bangunan. Adapun beberapa fasade 
bangunan komersial berfungsi sebagai elemen fisik bangunan dan identitas terkait fungsi komersialnya. Begitu juga bangunan tempat ibadah dan perkantoran. Fasade atau wajah bangunan colonial menurut Rahmi dan Roychansyah (2017) dapat dikategorikan pada unsur atap, bukaan jendela dan warnanya.

Pada kasus bangunan utama kota lama (Marba, Gereja Blenduk dan Jiwasraya) elemen warna, atap dan bukaan cukup memiliki kontras dan karakter yang kuat. Tanpa menggunakan warna pun dapat dilihat tingkat kontras dari 3 bangunan utama tadi terhadap sekitarnya. Begitu pula dengan fasade bukaannya yang terlihat kegelapannya yang sangat kontras dibandingkan dengan dinding bangunannya (lihat gambar 7). Untuk karakter bangunan Gedung Jiwa Sraya, Gedung Marba dan Gereja Blenduk akan dijelaskan lebih detail pada bab pembahasan dengan upaya tipologi.

Tipologi dapat diidentifikasi dari perubahan lingkungan fisik permukiman yang membentuk suatu kesatuan sistem (Habraken dalam (Lihawa et al., 2006), yaitu;

a.Sistem spasial (spasial system) adalah aspek tolak ukur terkait organisasi ruang atau keruangan. Sistem ini mencakup ruang, orientasi ruang dan pola hubungan ruang (pola spasial ruang).

b.Sistem fisik (physical system) adalah aspek tolak ukur terkait konstruksi dan penggunaan materialmaterial yang digunakan pada fisik bangunan. Sistem ini mencakup hal-hal yang berkaitan dengan struktur, konstruksi atap, dinding dan lantai.

c.Sistem model (stylistic system) adalah aspek tolak ukur yang berkaitan dengan model atau langam yang mewujudkan bentuk. Sistem ini meliputi fasade, bentuk pintu dan jendela, serta unsur-unsur lain baik didalam maupun di luar bangunan

Menurut Rafael Moneo (1994) analisis tipologi dibagi menjadi 3 fase yaitu:

a.Menganalisa tipologi dengan cara menggali dari sejarah untuk mengetahui ide awal dari suatu komposisi; atau dengan kata lain mengetahui asal-usul atau kejadian suatu objek arsitektural

b. Menganalisa tipologi dengan cara mengetahui fungsi suatu objek

c.Menganalisa tipologi dengan cara mencari bentuk sederhana suatu bangunan melalui pencarian bangun dasar serta sifat dasarnya.

Sehingga dalam pembahasan nanti tiap bentukan struktur formal fasade akan dikaitkan dengan aspek model, fisik dan fungsinya untuk dapat ditarik suatu kesimpulan tentang struktur formalnya terhadap satu bangunan maupun satu lingkungan kota lama.

\section{Pembahasan Struktur Formal pada Bangunan Gereja Blenduk}

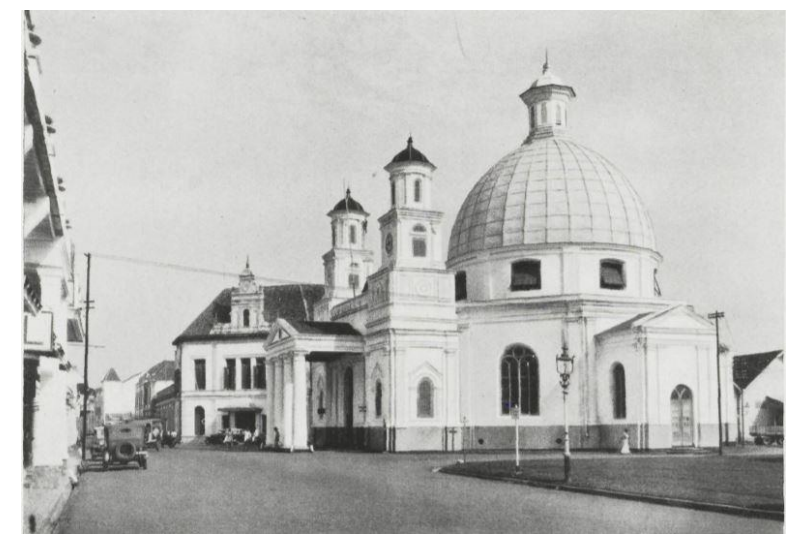

Gambar 7. Struktur Formal Fasade pada Gereja Blenduk masa lalu (Brommer,1995)

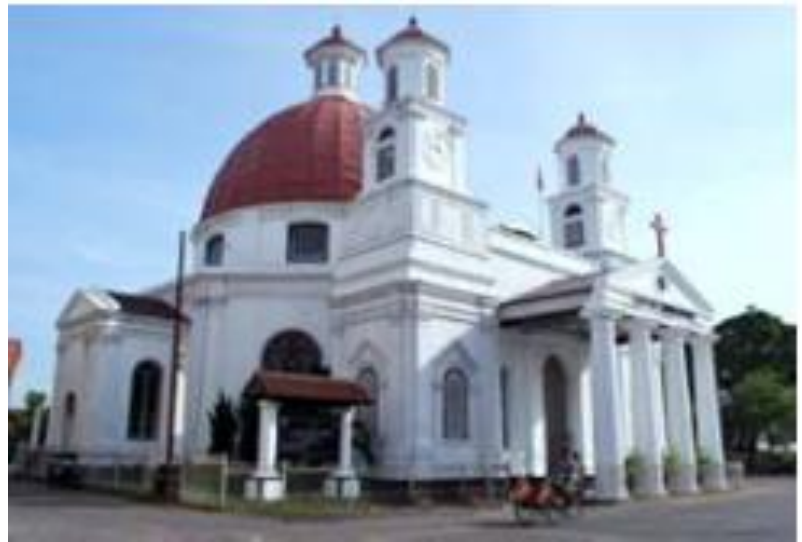

Gambar 8. Fasade Pintu Depan Gereja Blenduk

(Rahman, 2009)

Pada kasus Gereja Blenduk elemen warna, atap dan bukaan cukup memiliki kontras dan karakter yang kuat. Pada gambar 7 dan 8 dapat diketahui bahwa pewarnaan yang diterapkan pada Gereja yang bernama resmi GPIB Imanuel ini tidak mengalami banyak perubahan. Warna terang pada atap dan badan bangunan dipadukan dengan elemen gelap pada kaki bangunan terjaga hingga saat ini. Apabila ditelisik lebih jauh warna awal atap mblenduk dari gereja mungkin lebih terang daripada warna yang sekarang (lihat gambar 9).

Proporsi kubah utama yang megah menjadi pusat pandangan yang memberikan karakter utama dari gereja ini. Terlebih lagi secara tampak dan situasi, keberadaaan kubah juga menjadi sumbu utama pembagi simetri bangunan yang menyatukan elemen-elemen fasade lain pada gereja ini.

Kubah ini seakan memberikan panduan bagi sebaran bukaan maupun ornamen estetis lain sesuai dengan skala dan proporsi fungsinya masing-masing. Karakter utama dari kubah mblenduk ini sendiri memberi identitas pada bangunan gereja yang 
seharusnya disebut Gereja Protestan Indonesia Barat Imanuel menjadi lebih dikenal dengan nama gereja Blenduk bahkan oleh jamaah dan pendetanya sekalipun.

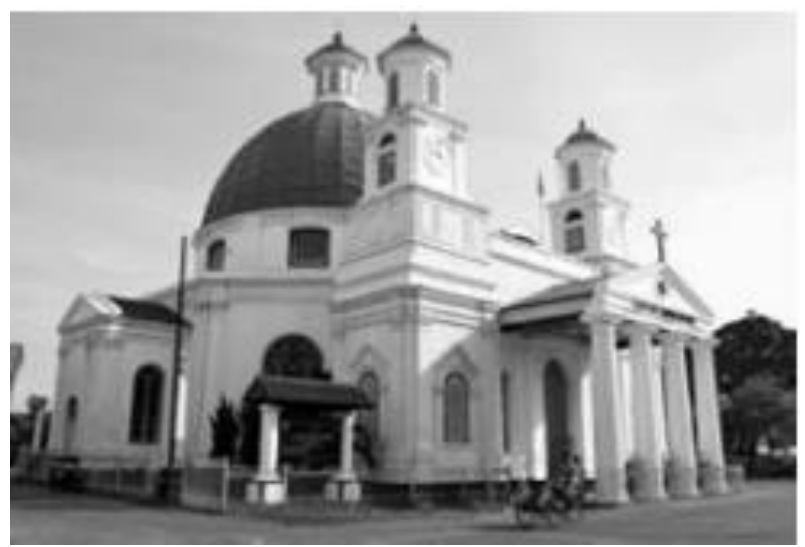

Gambar 9. Fasade Pintu Depan Gereja Blenduk dalam reproduksi hitam putih (Rahman, 2009)

Kontras terlihat jelas pada bagian bukaan dibandingkan dengan dinding bangunan yang terang. Dilihat sekilas maka akan ditemukan lokasi bukaan dinding (jendela dan pintu) pada deretan kolom dan tembok yang berwarna terang. Hal ini diduga karena kondisi pencahayaan di dalam gereja ini cukup gelap dan penggunaan material kusen-kaca yang tidak tembus cahaya sehingga area ini terlihat sangat kontras gelap terhadap dinding.

Pengulangan bentuk bukaan dan ornamentasinya membentuk suatu ritme untuk memberi bingkai kesatuan pada bangunan gereja kuno ini (Scruton, 1979).

\section{Pembahasan Struktur Formal pada Bangunan Jiwasraya}

Gedung Jiwasraya merupakan bangunan dengan tipe kantor yang dimiliki oleh Nederlansche Indische Levenzerkering en Lijvrente Maatschappij (NILMIJ) tahun 1916 yang sekarang telah dinasionalisasi oleh pemerintah dan dikelola BUMN asuransi Jiwa Sraya (Cantya, 2020). Penambangan baru Logo Jiwasraya terpasang jelas dengan warna merah pada dekat pintu utamanya untuk memberi informasi letak gerbang. Bagian yang menonjol dari fasade depan bangunan ini adalah bentukan $\mathrm{L}$ dari muka bangunan dan pengulangan bukaan jendela yang tipikal dengan pusat tengah dari tekukan L tadi (perhatikan gambar 10 dan 11).

Warna dari eks Bangunan NILMIJ ini hampir seluruhnya terang (dapat dikatakan putih). Bahkan kusen, kerawangan dan daun jendela-pintupun diwarna putih. Tetapi penggunaan warna putih pada seluruh bagian bangunan ternyata tidak mengurangi efek kontras terhadap bukaan dindingnya. Hal tersebut diduga karena kondisi dalam Gedung cukup gelap, tingkat kedalaman lubang dinding cukup tebal dan diperkuat dengan adanya koridor antara dinding terluar dengan ruang fungsionalnya.

Warna yang keseluruhan putih tersebut menjadi ciri khas dari bangunan Jiwasraya. Identitas lain yang dikuatkan adalah bentuk L bangunan yang secara komposisi tidak simetris dengan area pintu sebagai garis imajinernya.

Meskipun bangunan ini menggunakan atap kubah seperti gereja blenduk, tetapi tidak menjadi sesuatu yang ikonis dibandingkan bangunan di seberangnya. Skala dan posisi Gedung jiwasraya terhadap lingkungannya memberi kedinamisan pada aspek visual terlihat dan tersamar. Hal tersamar lain adalah keberadaan atap pelana pada bagian atas bangunan yang tidak terlihat karena proporsi lebar jalan dan tinggi bangunan membuat atap tidak dapat terlihat.

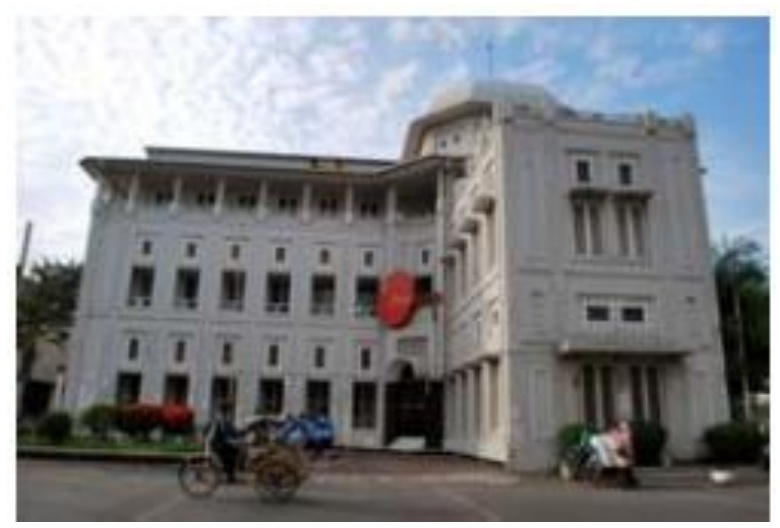

Gambar 10. Fasade Jiwasraya di Jalan Letjen Suprapto (Rahman, 2009)

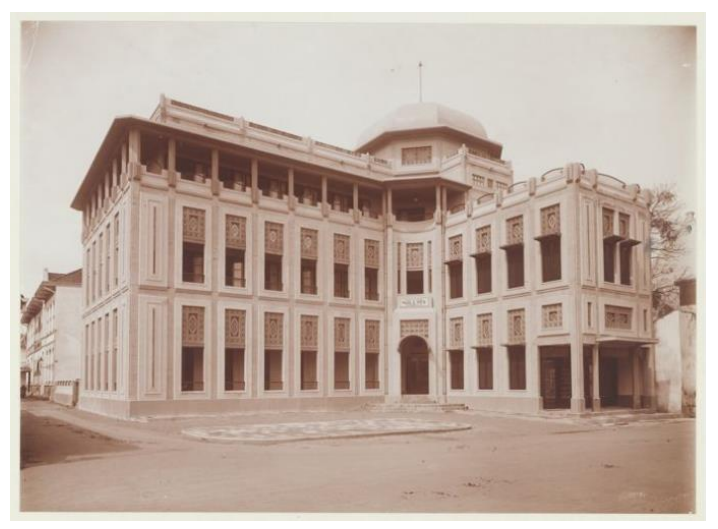

Gambar 11. Fasade Pintu Depan Jiwasraya (Budiman,1979)

\section{Pembahasan Struktur Formal pada Bangunan Marba}

Gedung Marba memiliki angka tahun 1894 atau bertepatan dengan pemugaran gereja Blenduk sebagai 
prakarsa pengusaha asal negara Yaman yang disebut dengan nama Marta Bajunet. Marba sendiri akronim dari pendirinya MARta BAjunet sampai sekarang dipasang diatas pintu masuk bangunan sebagai penanda utama gedung (lihat gambar 12 dan 13). Gedung ini adalah kantor perusahaan ekspedisi muatan kapal dan toko swalayan atau dulu dikenal dengan istilah toko modern dengan nama "de Zeikel” (Indraswara, 2011).

Bromer et al (1995) dan Indraswara (2011) sepakat bahwa gedung ini merupakan arsitektur transisi dari Indische Empire ke arsitektur tropis Hindia Belanda yang terjadi pada awal abad ke-19 dengan penerapan kaidah neoklasik yang disesuaikan dengan kondisi tropis di Indonesia terutama Semarang (Arsitektur Hindis).

Gedung marba ini memiliki warna yang cukup kontras terhadap sekitarnya yang mayoritas putih dengan pemilihan dinding berwarna dasar bata (merah). Hal ini menjadikan Marba menjadi elemen kontras Kawasan dengan warna bangunan.

Pada elemen bukaan sebagai ruang keluar masuknya cahaya, udara maupun manusia penempatan kusen yang tepat berada di bagian luar dinding dan tidak menjorok ke belakang menyebabkan marba memiliki bukaan yang berwarna terang meskipun diubah dalam efek hitam-putih (gambar 13).

Bentuk marba yang berpejal diduga merupakan ekspresi dari bangunan kantor dan toko yang mengoptimalkan petak yang ada. Hal tersebut juga dikuatkan dengan pemilihan lokasi kusen jendela dan pintu tepat dibagian luar dinding tanpa penaungan terlebih dahulu. Kondisi tanpa penaungan ini mengakibatkan pembuatan overstek dengan konsol pada sisi menghadap jalan utama dan pada zaman awal kemerdekaan terdapat elemen tambahan yang tidak konseptual berupa awning pada pintu masuk dan jendela (kihat gambar 13). Tetapi saat ini hanya awning jendela lantai 1 saja yang disisakan.

Posisi area pintu masuk bahkan dibuat menonjol melebihi garis sempadan bangunan di sekitarnya untuk mengoptimalkan tapak. Tonjolan pintu masuk membagi dua sisi lain dengan komposisi asimetris. Elemen pengulangan terjadi pada sisi bangunan seperti ornamentasi jendela, boven, konsol, awning bahkan pewarnaan dinding merah-putih yang digunakan untuk memberi aksen dan tanda bahwa bangunan ini memiliki bukaan, kolom, balok dan mahkota.

Seperti kasus Gedung Jiwasraya yang tidak terlihat atapnya. Gedung Marba ini memiliki atap pelana dengan mahkota simetri pada bidang muka pintu masuk. Skala dan posisi Marba terhadap sekitar membuat ada aspek vista terlihat dan tersamar. Hal tersamar itu adalah atap pelana dengan tipe mansard rendah pada bagian atas bangunan yang tidak terlihat karena proporsi lebar jalan dan tinggi bangunan membuat atap tidak dapat terlihat. Hal tersebut diduga karena usaha pemanfaatan maksimal terhadap luasan tapak efektif dan bentuk atap dianggap tidak estetis sehingga jurai dalamnya ditutupi oleh dinding mahkota dan ikon Marba.

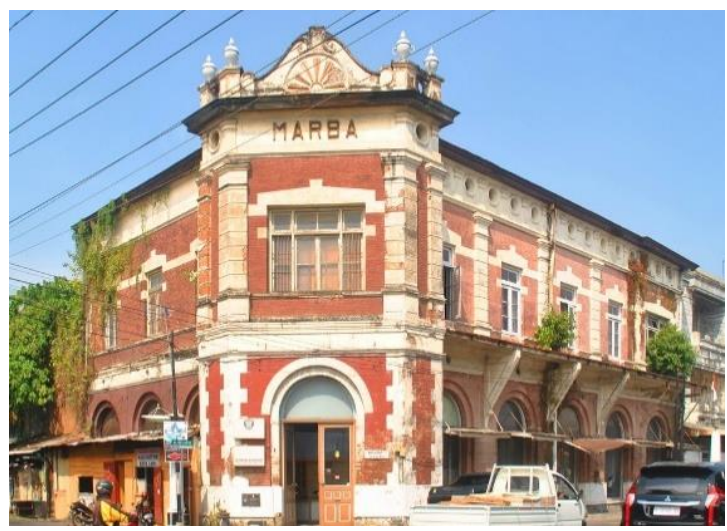

Gambar 12. Fasade Pintu Masuk Marba

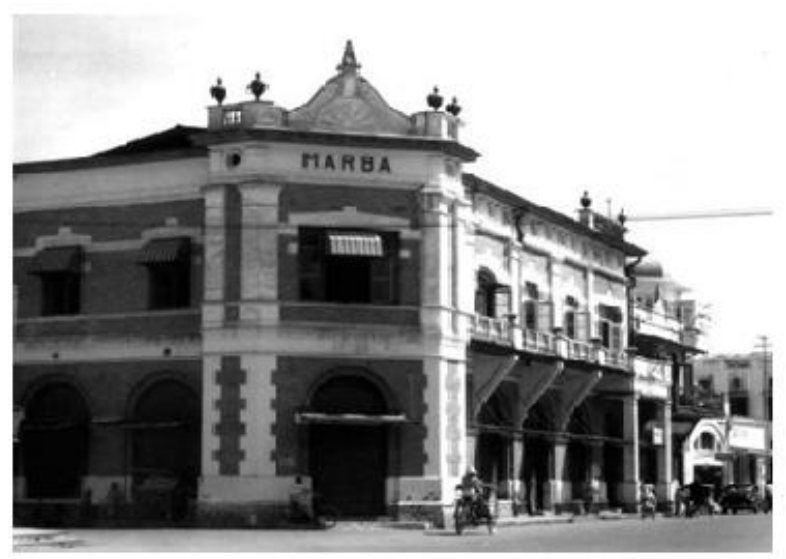

Gambar 13. Fasade Marba awal kemerdekaan (indraswara, 2011)

\section{Pembahasan struktur formal pada kawasan kota lama}

Gereja Blenduk, Gedung Marba dan Gedung Jiwasraya merupakan ikon pada Kawasan kota lama dengan cirinya sendiri-sendiri. Secara fasade ketiga bangunan ini memiliki karakter kontras yang berbeda dengan Gedung lain di pinggir jalan utama dan bahkan seluruh Kawasan kota lama Semarang.

Kontras dari Marba terhadap kota lama adalah warna merah dindingnya dan penonjolan sisi muka pintu utamanya. Gereja Blenduk memiliki atap mblenduk yang ikonik dengan ukuran besar yang mengakibatkan dapat terlihat dari beragam sisi kota lama, berbeda dengan atap kubah jiwasraya. Gedung Jiwasraya sendiri menunjukan kontrasnya dengan menarik muka bangunan ke belakang dengan bentuk L dan menyisakan ruang untuk taman di depan pintu utama. Ketiga bangunan dengan kontras bentuk, warna dan atapnya telah menjadi unsur pengikat Kawasan kota lama. Hal 
tersebut juga diperkuat dengan bentuk bangunan gereja Blenduk yang simetris dan memilik pusat-puncak berupa kubah yang berbeda dari bangunan lain. Blenduk juga otomatis menjadi pusat dari kota lama Semarang, meskipun berbeda dengan pusat pada desain awal kota benteng Vifthoek (lihat gambar 2)

Kesatuan ritme dan keseimbangan proporsi dari tiap bangunan di Kota lama jika dicontohkan oleh tiga bangunan utama ini adalah elemen bukaan dengan ornamentasi penegasannya. Meskipun berbeda-beda coraknya, semua bangunan di kota lama ternyata memiliki struktur formal berupa repetisi bukaan dan ornamentasi yang cukup banyak. Hal ini mungkin respon terhadap cahaya yang melimpah pada area tropis yang disebutkan oleh Brommer dan Indraswara sebagai bangunan arsitektur transisi Hindis.

Karakter unik dari tiga bangunan utama ini diduga karena posisinya yang terletak di jantung kota lama (area gereja blenduk) yang memiliki fungsi lebih beragam di bandingkan area lain di Kota Lama Semarang. Tetapi hal tersebut mungkin dapat terpatahkan dengan temuan penelitian lain di area kota lama yang menjelaskan ada bangunan kunci lain dengan karakternya dan lokasinya tidak di pusat kota lama.

\section{Kesimpulan}

Kota Lama Semarang memiliki perjalanan panjang sebagai area bersejarah yang terus berkembang di Indonesia. Bangunan di dalamnya silih berganti dihancurkan, dirombak maupun diganti oleh bangunan baru selama berabad-abad. Perkembangan yang terjadi ternyata tidak mengubah citra fasade kota lama Semarang menjadi area lain meskipun tidak dibangun pada satu era saja.

Keajegan dari fasade di Kota Lama ini menghadirkan struktur formal fasade yang secara alamiah terbentuk. Struktur formal fasade tersebut dapat terdeteksi dari warna kulit bangunan (dan lubangnya), tampilan bukaan (dan ornamentasinya), dan bentuk atap (dengan respon jarak pandang lingkungan).

Komposisi fasade yang dihasilkan atap, warna kulit, dan tipe bukaan pada aspek kontras, proporsiskala, ritme memberikan karakter dan kesatuan vista pada ketiga bangunan utama di Kota Lama Semarang ini. Karakter unik ini juga diperkuat oleh posisinya terhadap keseluruhan Kawasan Kota Lama yaitu pada pusat atau jantung distrik bersejarah ini.

\section{Saran}

Riset struktur formal fasade pada tiga bangunan utama di Kota Lama ini menemukan karakter inti pusat Kawasan kota lama. Penelitian lanjutan pada Kawasan pinggir atau simpul-simpul lain Kawasan dapat dilakukan untuk memperkuat karakter fasade kota lama Semarang sehingga dapat ditemukan suatu panduan desain di Kawasan ini. Panduan tersebut dapat dijadikan tonggak pembuatan atau konservasi Kawasan Kota Lama Semarang ataupun daerah lain di dunia dengan metode penggalian struktur formal dari beragam latar belakang bangunan.

\section{Daftar Referensi}

Brommer, B, et.al., (1995) Beeld van Een Stadt, Asia Major, Nederland.

Budiman, A. (1979) Semarang Juwita. Penerbitan Satyawacana, Semarang

Cantya, D. (2020) Mengulas Sejarah Gedung Jiwasraya Semarang. Solopos.com diakses tanggal 25 april 2020

Ching, F.D. (2007) Form, Space, \& Order (Vol. 3). new jersey: John wiley \& sons.

Gamble, J (2014) Alvar Aalto: Formal structure and a methodical development of an inclusive architecture. PhD Dissertation, UNSW

Harsritanto, B.I.R. et al. (2018) Study of Outdoor Thermal Comfort in Old City Openspace, Case Study Semarang Old City. Advanced Science Letters, Vol. 24, 9548-9551

Indraswara, M.S. (2011) Kajian Konservasi Gedung Marba. Modul, vol 11 no 1: 49-54.

Jefferis \& Madsen (1986) Architectural drafting and design. USA: Thomson Delmar Learning.

Krier, R. (1996). Komposisi Arsitektur, Jakarta : Erlangga

Lihawa, H. R., Suwarno, N., \& Nuryanti, W. (2006). Tipologi Asitektur Rumah Tinggal Studi Kasus Masyarakat Jawa Tondano (Jaton) Di Desa Reksonegoro Kabupaten Gorontalo. Jutap UGM: $1-15$

Moneo. R. (1994) On Typology: Ordering Space Type in Architectureil Design. Van Nostrand Reinhold, NewYork

Pazooki, S. (2011) The Application of Formal Aesthetics by Architects and Interior Architects According To Their Own Ranking Performances. Master Thesis. Eastern Mediterranean University

Purwanto, L.M.F. (2005) Kota Kolonial Lama Semarang (Tinjauan Umum Sejarah Perkembangan Arsitektur Kota). dimensi teknik arsitektur, Vol 33, No. 1: $27-33$.

Rahman, I.F. (2009) Arsitektur Kota Lama Semarang sebagai objek dalam kartu pos. skripsi S1. Unnes

Rahmi, A, Roychansyah, M.S. (2017) Tipologi Arsitektur Fasad Bangunan Kantor Kolonial diKawasan Kota Lama Semarang. Temu Ilmiah Ikatan Peneliti Lingkungan Binaan Indonesia $\begin{array}{llll}\text { (IPLBI) } \quad 6, & \text { I } & \text { 033-038. }\end{array}$ (https://doi.org/10.32315/ti.6.i033)

Salyan, G., \& Thapa, S. (2000) Architectural and Construction data Quezen city. JMC Press. 
Sari, S.R., Harani, A.R., Werdiningsih, H. (2017) Pelestarian Dan Pengembangan Kawasan Kota Lama Sebagai Landasan Budaya Kota Semarang. Modul, vol 17, no 1: 49-55.

Scruton. R. (1979) the aesthetic of architecture. london: mathuen \& co LTD.

Setioko, B., Harsritanto, B.I.R (2017) Transformasi Bentuk Dan Pola Ruang Komunal di Kota Lama Semarang. Modul, vol 17 no 1: 11-16. 